\title{
Indonesia's 'new despotism'
}

Edition 5, 2021

Dr Airlangga Pribadi Kusman \& Dr Milda Istiqomah

DOI: 10.37839/MAR2652-550X5.13

Indonesian democracy has been decaying under the leadership of President Joko Widodo. There are numerous significant examples: the banning of Hizbut Tahrir in 2017, the more recent weakening of the Corruption Eradication Commission (Komisi Pemberantasan Korupsi, KPK), the sudden enactment of the so-called Job Creation Law; as well as the banning of Islamic Defenders Front (Front Pembela Islam - FPI) and the fatal shootings of its members.

Existing analyses focus on Jokowi's 'illiberal tendencies' demonstrated through the weakening of democracy, civil rights and the transparency of the institutions of government, along with the strengthening of established politico-business alliances.

What is missing from this discussion is the Jokowi government's use of the instruments of law to defeat the rule of law, and use of new and mainstream media to manipulate public opinion. The way in which the government defends the concentration of wealth and power while keeping public support can be explained through the concept of 'new despotism'.

\section{The New Despotism}

Scholar John Keane sketches a future world dominated by what he calls new despotism, 'a new type of pseudo-democratic government led by rulers skilled in the art of manipulating and meddling with people's lives, marshalling their support, and winning with their conformity'. The new despotism is characterised by wealth, and the expansion of executive power by controlling the judiciary and undermining the 
rule of law, despite continued elections and the retention of constitutional protections relating to the separation of political and judicial power and the equality of citizens before the law.

Turkey under President Recep Tayyip Erdoğan is an example of new despotism. Erdogan and his AKP party came to power articulating the populist social justice language of Islamic groups. However, Erdoğan has gradually transformed Turkey into an example of new despotism by changing the constitution to enable him to hold the power until 2029, and imposing a two-year state of emergency after an attempted coup in 2016 which has resulted in the targeting of more than 160,000 members of the judiciary, academics, teachers, police and civil servants perceived to be dissidents. It could be argued that President Jair Bolsonaro in Brazil, Viktor Orban in Hungary, Emomali Rahmon in Tajikistan, Rodrigo Duterte in the Philippines, among others, are also examples of new despotism.

The new despotism is different to classic despotism, which refers to brute power and the enforcement of arbitrary law without people's consent. Unlike authoritarianism and military dictatorship, new despots don't depend on repression, unfree elections and a centralistic party system. The regimes of the new despotism require the existence of democratic institutions, and free and fair elections. Such regimes are more stable, attractive and resilient: a sophisticated way of governing that draws together 'the people' against their opposites. Combining the power of capital markets, technology, media as well as the armed forces, this kind of regime can be strong, durable and effective.

New despotism is also different to populism, which is characterised by creating political antagonism between the 'people' versus the elite. A fundamental characteristic of new despotism is that these regimes articulate themselves as elites standing at the top of political hierarchy.

New despotism is also different to illiberal democracy. There are some similarities: the quality of the freedom, the interaction between political and economic 
institutions, and the weakening of public transparency. But Keane defines the new despotism as a new type of power with systematically $21^{\text {st }}$ century characteristics wherein a perverted form of democracy has the capacity to create social consent by manipulation.

\section{The new despotism in Indonesia}

In Indonesia, the growth of new despotism has occurred together with the hijacking of political reform and democratic institution building by predatory politico-business alliances and state forces.

Political reform after the Soeharto era (1967-1998) succeeded in building a multiparty system, freedom of the press, and the decentralisation of state administrative authority. But after the brief euphoria of reform after 1998, the oligarchic system remains intact. The current fusion between private wealth and political power is evident in the form of growing alliances between powerful political and business elites at the local level, due to decentralisation. Oligarchic forces have been able to adapt to democratic institutional arrangements and build new and pervasive social and political alliances.

The tendency of politico-business alliances to appropriate tangible state resources for their own interests undermines democratic institution-building. The last three years of the Jokowi administration have shown a tendency to overcome contradictions between institutional reform and oligarchic interests, which has led to creeping new despotism.

Why is the oligarchy is transforming institutional processes along the lines of new despotism if they can advance their interests through illiberal means? Statements by the President provide some clues. He has said that Indonesia is too democratic and that this could result in foreign ideologies such as liberalism and terrorism threatening Indonesian sovereignty; and that his government's primary focus is 
stimulating economic growth. These comments indicate that he President does not regard Indonesian democracy and liberal political norms as important as stability and economic performance. This perspective is similar to that of the Soeharto era, and during the leadership of Jokowi political compromise has been skewed in the interest of the oligarchy, rather than reform.

\section{State forces and government's response to terrorism}

One of the key elements of new despotism is the major role of state forces, particularly in responding to acts defined as terrorism. Democracies everywhere, including Indonesia, have been gripped by a culture of surveillance, linked to the 'war on terror' discourse, which has militarised the policing of civil society. In Indonesia, the history of authoritarianism and the centrality of military forces in Indonesian politics, particularly the politics of counterterrorism, may enhance the durability of the new despotism.

During Soeharto's New Order era, the Indonesian Armed Forces (Angkatan Bersenjata Republik Indonesia, ABRI) acted as a propaganda machine which presented itself as a saviour and creator of Indonesia against Dutch colonial rule and the key to safeguarding the integrity of the state. It was able to extend its structure into all levels of national, provincial and district government.

Soeharto's regime also represented itself as the saviour and guardian of Pancasila (the founding philosophy of Indonesia), which legitimatised his rule and silenced his opponents. Anyone who fought for human rights and democracy was branded antiPancasila and against a communal, consensus-seeking and harmonious society.

Twenty years after the start of the reformation era, this kind of government response is being imitated by the Jokowi administration. This is seen in the banning of the Hizbut Tahrir Indonesia as mentioned earlier, which was done in the name of 
guarding and protecting Pancasila, with the group being labelled as un-Indonesian.

The 'war on terror' discourse also legitimises and justifies how the government deals with the issue of terrorism more broadly. The 'war on terror' after the Bali bombings in 2002 has contributed to repressive policies. Since it was established in 2002, the counterterrorism special forces known as Densus 88 (Detachment 88) have gained international praise for its success in counter-terrorism, having conducted major investigations related to those involved in the Bali bombings including Amrozi, Imam Samudra and Muklas.

Despite these impressive achievements, the counterterrorism operations conducted by Densus 88 have been accompanied by a number of allegations of extra-judicial killings and serious human rights violations. For example, in December 2020, six people believed to be members of Front Pembela Islam (FPI, Islamic Defenders Front) were killed by police in a highway shootout. A few weeks after the incident, the FPI head and founder Rizieq Shihab was alleged to have breached COVID-19 restrictions and arrested; and the FPI was banned by the government. Some observers have called for transparency into exactly what happened during the shootout, and raised questions about the legality of the banning of the FPI.

The use of coercion and repression has dominated the history of Indonesian counterterrorism. For example in 2016, a military operation was conducted in Poso, Central Sulawesi to eliminate the threat posed by the extremist group East Indonesia Mujahideen (Mujahidin Indonesia Timur, MIT) in the region. At least 3,000 members of the security forces including 1,543 police and 1,791 military members were deployed in Poso to weed out the MIT group, which consisted of 50 poorly resourced armed men. The operation resulted in several MIT members being killed and took a significant toll on the local population.

More worryingly, in 2018 the Parliament enacted the new Anti-Terrorism Law that potentially jeopardises the protection of human rights and the criminal justice system. It's also an example of the success of the military in securing its interests, 
because the new law specifies that the military should be involved in the fight against terrorism: Article 43I states that the role of the Indonesian Armed Forces (Tentara Nasional Indonesia, TNI) is part of combating acts of terrorism'.

The involvement of military forces in counter-terrorism should be critically examined, especially the possibility of the abuse of power. The militarised policing of society may be used as a mechanism to re-gain economic and political power by the police and military under the pretext of law enforcement. The 'war on terror' has brought the Indonesian military back to the centre of the political stage.

Understanding the historical and political contexts of the Soeharto regime and its military underpinnings may provide a fuller explanation of how the military, as an important element of new despotism, has been able to maintain certain sites of power so that it can enter into competition for control over tangible state resources, given its long history of interests in the economic sphere.

\section{Creating the nation's enemy and mobilising social media}

New despotism is characterised by the sophisticated use of media by the government, especially online media and social media networks. It is different to state propaganda because democratic elements such as a free media are maintained.

The Jokowi administration shows the characteristics of new despotism through its creation of a discourse of cultural antagonism which criminalises its opponents from civil society and which helps build public approval. This was seen, for example, in the framing of groups who were critical of the weakening of the Indonesian AntiCorruption Commission (KPK). The government erroneously claimed that the KPK had been infiltrated by radical Islam groups-resulting what the government alleged was the 'talibanisation of KPK'. This discourse was advanced through influencers and 'buzzers' on social media. 
It should be noted that the Jokowi administration is prepared to go further than the stigmatisation of its opponents through media manipulation. In 2017, the government banned the Hizbut Tahrir Indonesia (HTI) as a 'radical' Islamic group-a move which could be seen as suppressing freedom of expression.

\section{Rule through law}

Keane writes that under new despotism, the law appears to triumph, yet the ruling elites ensure that the law, the courts and law enforcement institutions side with the powerful. The amendment of the KPK Law as well as the Job Creation Law are strong indications that the Jokowi administration protects oligarchic power. Instead of pursuing the 'rule of law', his government legitimises their actions through legal change.

The KPK Law introduced in 2019 requires commissioners to seek the supervisory council's consent to undertake wiretapping, searches and confiscation. The change effectively removes the Commission's independence from the executive and cuts its authority. Jokowi had promised before the 2014 presidential election to tackle corruption, but instead politico-business alliances have succeeded in shackling reform. It should be noted that the government of Soesilo Bambang Yudhoyono (2004-2014) had tried eight times to weaken the KPK's authority, but was unsuccessful due to public pressure. Under the Jokowi administration, the majority of political elites in legislative and executive were united kn reducing the authority of anti-corruption commission on the pretext that it had become too powerful.

This kind of political manoeuvre has also occurred in the process leading to the Job Creation Law, which the government claims will improve the process of conducting business in Indonesia and advance national investment by amending overlapping laws and/or regulations that are deemed to be unfavourable for foreign investors. However, it relaxes requirements for environmental impact analyses (Amdal) and gives the central government authority over approvals. Further, the Job Creation 
Law limits public participation in environmental impact analyses; and the Appraisal Commission of Environment Analysis, an auxiliary body which involves intellectuals and environment activists, has been replaced by an Assessment Body run by the central government (Lembaga Uji Kelayakan). These provisions show political elites have weakened environmental provisions to bring about more opportunities for business at the expense of the natural environment and public scrutiny.

The examples of the two laws above show that political elites under the Jokowi administration have succeeded in winding back reform to serve the interests of oligarchic power.

\section{The future of democracy}

The last three years have seen the creeping new despotism of the Jokowi administration, through political elites' manoeuvres to manipulate the law in order to weaken democratic principles, together with pro-government social media influencers creating widespread support. The Jokowi government has manipulated the law and utilised coercion to repress its political opponents and undermine Indonesian democracy. This enables oligarchic interests to crush the rule of law and replace it with rule through law. This makes Indonesia more susceptible to both corruption and state surveillance of public life. It is too early to announce the death of Indonesian democracy, but it's not clear how can its decay can be stopped.

Authors: Dr Airlangga Pribadi Kusman and Milda Istiqomah

Image: President Joko Widodo. Credit: Kreshna Aditya 2012/Flickr 